\title{
On Publicity Channels of Red Star over China and Their Impact
}

\author{
Yong $\mathrm{CHEN}^{1,{ }^{*}}$ and Bu-fen $\mathrm{HU}^{1}$ \\ ${ }^{1}$ School of Foreign Languages, East China University of Technology, \\ Nanchang, Jiangxi, P.R. China
}

Keywords: Red star over China, Edgar snow, Publicity channels, Book reviews.

\begin{abstract}
The publication of Edgar Snow's Red Star over China by V. Gollancz in 1937 in London exerted significant influence on people all over the world. Its great impact has substantial connection with the three major channels of publicity-the appearance of the book's main content on major English newspapers and magazines in western countries before the publication of the book, the repeated publications of the book in western countries since 1937, and the favorable comments made by various book reviewers on major English newspapers and magazines since its first publication. The combination of these three factors has made Red Star over China a classic for those who want to know Chinese Communists and the Reds.
\end{abstract}

\section{Introduction}

Edgar Snow, the well-known American journalist and man of letters, is a real China interpreter. He is famous for Red Star over China, which for the first time introduces the true state of Chinese Communist Party (CCP) and her Red Army to the whole world. Since its first publication by Victor Gollancz in London in 1937, it has been reprinted for over 167 times and has been considered to be the classic and fundamental textbook for those who would like to read Chinese Communists and Revolution [1]. Today, it has become an important text for the studies of journalism, literature, history of CCP, etc. The fact that this book has so big an impact on the world is due largely to its various channels of publicity, in addition to its magnetic attraction of content to the readers. The three main channels of publicity-the wide-range reports of the main content of the book before its official publication, the continuous reprint of the book in English world and the promotion of major book reviews in the Western world-have contributed to the great impact of the book all over the world. As for the influence of Red Star over China in China as well as abroad, there have been articles dealing with it, however, few probe the process and specific channels of publicity that contribute to the forming of impact among the readers. The study of the publicity channels of this book would undoubtedly help understand the publicity of Chinese culture and the acceptance by foreign readers.

\section{Reporting of the Main Content before Its Official Publication}

The main content of Red Star over China and Snow's traveling experiences in the Red area in Northern Shenxi Province have been reported on newspapers and magazines in China and abroad before the book was first published in London in October, 1937, which has laid a solid foundation in media for the readers' expectation and acceptance. Snow's reports of Red area first appeared in the Shanghai-based English newspaper China Weekly Review in November $1936^{1}$. China Weekly Review, the oldest American

\footnotetext{
${ }^{1}$ See Edgar Snow, “Interviews with Mao Tse-tung, Communist Leader", China Weekly Review, LXXVIII (November 14,21,1936), 377-379,420-421.
} 
weekly newspaper in China with a circulation of four to five thousand copies, was well-known in China since its readers were mainly Chinese government officials, businessmen, professionals and intellectuals. As some copies were also sold in English speaking countries, it also had influence among the foreign readers [2]. On October 25, 1936, Paris-based Chinese language newspaper Jiuguo Times reported that Red Army had met and was marching northward to fight against Japanese invasion, the source of this piece of news was China Weekly Review [3]. In fact, news about CCP and Red Army in Northern Shaanxi (Shensi) made by Snow had already appeared in newspapers outside China before the publication on China Weekly Review. Snow returned Peiping on October 25, 1936, and two days later word got round that he was executed by Red Army, so he decided immediately to clear the rumors at a news conference in American consulate in Peiping. Snow's talk about his journey in northern Shaanxi spread through news agencies like Associated Press and Reuters, which, in turn, flew back into China and was published by major newspapers in Far East,catching many readers' attention. Even the Jiuguo Times published the news about Snow's journey in the Soviet area, and its source was the London Daily Herald and news agencies like Associated Press and Reuters. When China Weekly Review and London Daily Herald cooperated and published Snow's interview of Mao Tse-tung, Jiuguo Times followed their steps, translated the reports into Chinese and published on December 20, 1936. It also published another two feature reports about Mao Tse-tung and Chou En-lai [3]. Before the end of 1936, London Daily Herald first published Snow's serialized reports about his journey to the Red area with related editorials and display of big photographs on front pages, together with the Xi' an Incident on December 12, great interest of English readers was aroused [4]. These exclusive reports based on first-hand materials by Snow laid the foundation for the spread of the book in a wider range in 1937.

In 1937, English media in China had a wider coverage on Snow's reports on Red areas in northern Shaanxi. In February, "Reds and Northwest: A Visitor to Communist Areas Tells His First-Hand Observations" (based on the long speech which Snow had delivered before the Men's Forum of Peking Union Church on January 21) was published successively by Gould's Shanghai Evening Post and Mercury ${ }^{2}$, and almost at the same time, Snow's report on Chinese Soviet was also published by Paris-based Jiuguo Times and English Beijing Chronicle. Soon, Peiping-based Democracy published "Soviet Strongman" by Snow and his other articles on his Soviet journey were successively published since May and were reprinted by English- and Chinese-language periodicals, which has inserted great impact on readers home and abroad [4]. From May 1 to July 8, with a brief life of two months, Democracy magazine had provided a valuable channel for spreading excerpts from Snow's Red Star. "To our astonishment", Snow wrote in 1940, "the magazine proved very popular, and subscriptions were coming in nicely when we had to fold up". Hubert Liang, the journalism chair at Yanjing and a member of the editorial board, wrote to Peg decades later, with some hyperbole, that the magazine had been "an immediate, sensational success, taking China's intellectual world by storm"[5].

English media abroad also had a wide coverage on Snow's visit in northern Shaanxi before the publication of Red Star. From late 1936 to early 1937, some 30 of Snow's serialized report about Red China, the core of Red Star, had been published by London Daily Herald [5]. In the United States, Life took the lead and published seventy-five of

\footnotetext{
${ }^{2}$ See Edgar Snow, "Reds and Northwest: A Visitor to Communist Areas Tells His First-Hand Observations", Shanghai Evening Post and Mercury, February 3, 4, 5, 1937, 10-11.
} 
Snow's best photographs taken in Red China ${ }^{3}$, which depicted the vivid life of the wives of Communist officials, contented children of the Red Army, etc. In February, Asia published Snow's "Direct from the Chinese Red Area", and the famous serialized report of Mao Tse-tung's autobiography as told to Snow in four parts, plus Snow's account of the Long March of the Red Army in two installments from July to November ${ }^{4}$. During this period of time, Amerasia published Snow's interview with Mao Tse-tung ${ }^{5}$, stating the foreign policies of CCP. In August and September, New Republic published Snow's serialized report of "Soviet Society" in four parts ${ }^{6}$, Pacific Affairs published "Soviet Society in Northwest China" in September", and Saturday Evening Post published "I Went to Red China"8 in November just before the official publication of Red Star in the U. S. These reports before the publication have laid a solid foundation for the acceptance of the book.

\section{Official Publication and Dissemination of Red Star over China}

Red Star over China was first published by London-based Victor Gollancz in October 1937. As it was a selection of the Left Book Club, it became an immediate success and was reprinted three times within just one month, selling over a hundred thousand copies in its first weeks [4]. The popularity of the book made Random House, its American publisher, publish the book in advance on January 3, 1937. One month after the publication, the selling reached twelve thousand copies, and the total selling of Random House edition reached twenty three thousand and five hundred copies, not including the reissuance of Modern Library series of twenty seven thousand copies in 1944[5]. The total selling of the book till the publication of Journey to the Beginning was sixty five thousand copies, a new high for a non-fictional work on the Far East. What is interesting is that, in Moscow in 1938, there was the Russian edition of Red Star over China (Heroic People of China), with very big revision and deletion of the content that annoyed the Russian government, and Mao's autobiography was relegated to a final section with less than a page of only his career as a Communist. Twenty five thousand copies of this condensed edition of only one hundred and eight pages was printed in Russia, compared with the four hundred and seventy four pages of the Random House edition[5]. Though seriously revised, the Russian edition still promulgated the ideas of Chinese Communists and revolution.

\footnotetext{
${ }^{3}$ See "First Pictures of China's Roving Communists", Life, II (January 25, 1937), 9-15; "An Army of Fighting Chinese Communists Takes Possession of China's Northwest”, ibid. (February 1, 1937), 42-45. ${ }^{4}$ See Edgar Snow, "Direct from the Chinese Red Area", Asia, XXXVII (February 1937), 74-75;

"Boyhood of a Chinese Red: The Autobiography of Mao Tse-tung", ibid. (July 1937), 480-484;

"Schooling of a Chinese Red: The Autobiography of Mao Tse-tung", ibid. (August 1937), 570-576; "How the Red Army Began: The Autobiography of Mao Tse-tung”, ibid. (September 1937), '619-23; "The Red Army in Action: The Autobiography of Mao Tse-tung”, ibid. (October 1937), 682-688; "The Long March”, ibid, (October 1937), 689-692; “The Long March: Part II”, ibid. (November 1937), 741-747.

${ }^{5}$ See Edgar Snow, "Chinese Communists and World Affairs: An Interview with Mao Tse-tung", Amerasia, I (August 1937), 263-269.

${ }^{6}$ See Edgar Snow, "Soviet China I: What the Chinese Communists Want", New Republic, LXXXI (August 4, 1937), 351-354; "Soviet China II: The Long March”, ibid, LXXXII (August 11, 1937), 9-11; "Soviet China III: Chinese Communist Industry", ibid (August18, 1937), 42-44; "Soviet China IV: Moscow and the Chinese Communists", ibid (September 8, 1937), 124-125.

${ }^{7}$ See Edgar Snow, "Soviet Society in Northwest China", Pacific Affairs, X (September 1937), 266-275.

${ }^{8}$ See Edgar Snow, "I Went to Red China: The inside Story of China's United Front against Japan", Saturday Evening Post, CCX (November 6, 1937), 100-103.
} 
After the first publication of the book in both England and America, Snow has made revision and amendments to the original one, important editions of which were the so-called 1938, 1944, 1968 and 1971 editions respectively. For many decades, the book has been printed endlessly by Victor Gollancz (in 1937, 1938, 1944, 1963, 1968, 1973), New York Random House (in 1938, 1944), New York Grove Press (in 1961, 1968, 1971 , 1973), New York Garden City Publishing Co. (in 1939), Penguin Books in Harmondsworth (in 1972), and New York Bantam Books (in 1978). It has also been translated into over eighteen languages and spread all over the world. Although revised and amended, the original style of the book has not been changed, and is still the textbook for Westerners. Of course, the influence of the book is not limited to the English world.

\section{Reviews of Red Star over China and Their Influence}

Various comments from book reviews have contributed to the popularity and acceptance of Red Star. These comments, whether positive or negative, have objectively promoted the spread of the book. In the United States alone, "a sampling of more than one hundred reviews in general circulation publications reveals not a single one that offered an overall negative assessment" [4], mainstream reviews were lavish in praise. On October 11, 1937, immediately after the publication of the book, London Daily Herald declared it an "epic story, superbly told" [5]. On November 6, The New Statesman and Nation published an article by Freda Utley, a British journalist, commenting that "Edgar Snow is the first foreigner to have penetrated to the Chinese Soviet regions,... to have made a thorough study of every phase of life in Soviet China", that "in parts it reads like some adventure story for boys in which the endurance, courage and resource of this army surpasses anything in legend or imagination, and the crossing of the River Tatu alone is an almost unbelievable feat [6]". Utley also recommended this book to those British Conservatives who thought that a peace could be imposed on China by forcing her through "mediation" to give Japan the control of the North (of China). On New Year's Day, Saturday Review of Literature featured Snow on its cover to recognize his contribution in the journalism. Shewmaker even believed that perhaps the greatest compliment was paid by the anti-communist Far Eastern authority for the New York Herald Tribune, ${ }^{9}$, Rodney Gilbert, who accepted most of Snow's conclusions and christened him 'the' Occidental authority on Chinese communism [7].

More comments appeared after the official publication of the book in the United States. On January 8, 1938, Nation published a review by Eliot Janeway ${ }^{10}$, and on the same day, Evening Express in Portland, Maine praised the book "a dazzling journalistic feat ${ }^{11 "}$. The next day, New York Times published a review by R. L. Duffus, with photographs of Mao Tse-dung and Chu Teh, commenting that "what Mr. Snow is describing is one of the major facts of modern history, as well as one of the most dramatic", that "the significance of Red China is not that it is red but that it is Chinese and that it may portend the long-predicted 'awakening' of the Chinese people and the ultimate frustration of Japanese imperialism", and "that the 'Red bandits' bear a close resemblance to people whom we used to call patriots"[8]. In a word, the Red Star is a

\footnotetext{
${ }^{9}$ See Rodney Gilbert, "A Chinese State Hitherto Unknown to Us: The First Authentic Report of What Goes on among China's Reds", New York Herald Tribune Books, January 2, 1938, 1-2.

${ }^{10}$ See Eliot Janeway, "Red in the East”, Nation, CXLVI (January 8, 1938), 48.

${ }^{11}$ See B.C., Evening Express, January 8, 1938.
} 
symbol of hope and freedom and the very sense of tremendous destinies makes the reading of this book a shattering experience. Milwaukee Journal, an influential paper in the Middle West, said on the same day that "you cannot help finding a degree of similarity in the faith of these young Chinese Communists and that of primitive Christians" [4]. In his hometown, the Kansas City Star reported that "Edgar Snow, whose recently published book, 'Red Star Over China', has attracted favorable reviews throughout the country and finds himself a recognized authority on a confusing and complex country" [4]. On January 12, New Republic published a review by Malcolm Cowley $^{12}$; On January 23, Florida Times-Union published a review by David Lord ${ }^{13}$, both with favorable comments on the book.

One month after the publication of the book in the United States, more comments appeared by China or Far East experts. On February 12, Publisher's Weekly ${ }^{14}$ published Cerf's comment, saying that it was "almost a miraculous break just in time to have the headlines on the front pages of every newspaper in the country act as an advertisement for our book![5]" Two weeks later, Wisconsin State Journal ${ }^{15}$ published favorable review on the book. Still in February, Amerasia published review by E. Herbert Norman $^{16}$, saying that it was the most reliable account of the Chinese Red Society movement in the English language, and Current History ${ }^{17}$ published similar reviews by Cousins. In March, Pacific Affairs published a review by Edward C. Carter, the secretary-general of the Institute of Pacific Relations, declared that "the book was to mark an epoch, not only in his own journalistic career, but in the understanding of China today" as an important handbook for historian as well as political scientist [9]. On March 13, Knoxville Sentinel ${ }^{18}$ published Bruce Catton's reviews. Still in March, Asia published reviews by Pearl Buck ${ }^{19}$, the celebrated author of The Good Earth, saying that "the book was intensely readable and extraordinary, packed with incident and information, living with unforgettable character sketches, every page of it is significant" [5]. There was also recommendation of this book in "New Books of Interest in the Far East" of The China Weekly Review ${ }^{20}$. In May, Atlantic Monthly ${ }^{21}$ published Walter H. Mallory's review. In June, American Historical Review published C. H. Peake's review, saying that "his account of his sojourn has been widely hailed as an outstanding piece of reporting, ...his descriptions of life ... based upon extended firsthand interviews, have a sound ring of authenticity and sincerity.... Because of the unique character of the material presented, the work becomes a prime source for historians of contemporary China" [10]. The second issue of Pacific Affairs in 1938 published articles of an argument between Asiaticus and Snow, which actually promoted the popularity of the book. In his article, Asiaticus accepted that Red Star was an excellent and outstanding piece of reporting, a unique historical contribution in spite of his strong criticism of the book [11]. In the summer issue of Yale Review, Owen Lattimore, well-known China expert, called the book the biggest journalistic coup in years ${ }^{22}$. In the summer issue of

\footnotetext{
${ }^{12}$ See Malcolm Cowley, "Red China", New Republic, XCIII (January 12, 1938), 287.

${ }^{13}$ See David Lord, Florida Times-Union, January 23, 1938.

${ }^{14}$ See Bennett Cerf, “A Matter of Timing”, Publisher's Weekly, February 12, 1938, 838-839.

${ }^{15}$ See Wisconsin State Journal, February 27, 1938.

${ }^{16}$ See E. Herbert Norman, "Some Recent Books on China", Amerasia, I (February 1938), 573-574.

${ }^{17}$ See N. B. Cousins, "The World Today in Books", Current History, XLVIII (February 1938), 2.

${ }^{18}$ See Bruce Catton, Knoxville Sentinel, March 13, 1938.

${ }^{19}$ See Pearl S. Buck, “Asia Book-Shelf”, Asia, XXXVIII (March 1938), 202-203.

${ }^{20}$ See H. H. "New Books of Interest in the Far East". China Weekly Review. March 1938, p110-112.

${ }^{21}$ See Walter H. Mallory, "Red Star over China”, Atlantic Monthly, CLXI (May 1938).

${ }^{22}$ See Owen Lattimore, “The Chinese Communists", Yale Review, XXVII (Summer 1938): 814.
} 
New York-based Science and Society, HSIAO CHEN-KWAN commented that "Snow recorded the most dramatic, the most authentic, account of the 6,000-mile March of the Chinese Communists" and "to the majority of readers the book will not only provide important information about Soviet China and the Red Army, but also will change their traditional belief that the Chinese are a supine and ineffective people"[12], predicting the power and potentialities of the Chinese people in their struggle for liberation. All these reviews contribute to the popularity and acceptance of the book among the English readers.

\section{Conclusions}

Since its official publication in Britain in 1937 and the United States in 1938, Red Star over China has been reprinted for over one hundred sixty-seven times, and translated into over eighteen languages all over the world. The three channels-the wide-range reports of the main content of the book before its official publication, the continuous reprint of the book in the English world and the strong recommendation of major book reviews in the Western world-are indispensable in the wide spread and well acceptance of the book in the Western world, without which, English readers could not get a real understanding of Chinese Communists and WWII Chinese battlefield. Of course, the "timing" of the book cannot be overlooked. While Western readers were reading this book, battle for Shanghai, Japanese savage terror against civilian population of Nanking were headlines on front pages of western newspapers. Snow's book touched the readers' responsive chord and their searching for hero figures on a bleak future in Europe, Africa and Asia. To some degree, this is also the indication of its great impact on readers.

\section{Acknowledgements}

This research was financially supported by Jiangxi Social Science Foundation (project name: Red Star over China and the Spread of Red Culture, 14WX319)

\section{References}

[1] Wei Zhang, Crisis and Reconstruction: Edgar Snow's Last 30 Years of Life (in Chinese), Journal of Hangzhou Normal University, No. 2 (March 2011)55-61

[2] Guang-ren Ma, The History of Shanghai Journalism (in Chinese), Shanghai: Fudan University Press, 2014, p787

[3] Hong-wen Lan, Paris-based Jiuguo Times and the Long March (in Chinese), Chinese Journal of Journalism \& Communication, No.5 (September 2004)71-75.

[4] J. M. Hamilton, Edgar Snow: A Biography, Bloomington and Indianapolis: Indiana University Press, 1988, pp80-98.

[5] S. B. Thomas. Season of High Adventure: Edgar Snow in China. Berkeley: University of California Press, 1996, pp15-172.

[6] F. Utley. Communists in China. The New Statesman and Nation, XIV (November 6, 1937)766-767.

[7] K. E. Shewmaker. Americans and Chinese Communists, 1927-1945. Ithaca and London: Cornell University Press, 1971: p56. 
[8] R. L. Duffus. A Remarkable Survey of the Red in the Map of China. New York Times Book Review, January 9, 1938: BR3

[9] Edward C. Carter. Red Star over China by Edgar Snow. Pacific Affairs, No. 1 (March 1938)110-113

[10]C. H. Peake. Far Eastern History. American Historical Review, XLIII (June 1938)945-946.

[11] Asiaticus and Edgar Snow. Comment and Correspondence. Pacific Affairs, No. 2 (June 1938)237-252

[12] Hsiao Chen-Kwan. Red Star over China by Edgar Snow. Science \& Society, No. 3 (Summer 1938)420-423. 